\title{
CHEMOTHERAPY IN MALARIA CONTROL
}

$\mathrm{M}$ ASS chemotherapy has been used in malaria control programmes on a number of occasions. Where it is possible to issue pyrimethamine or chloroquin at weekly or even fortnightly intervals to all members of a community, rapid reduction of the parasite-rate will be achieved: under such conditions it is immaterial whether or not spraying is carried out. In experiments carried out in many parts of the world there has been a rise in parasite-rate after cessation of treatment because most of the experiments have been on small communities living in otherwise uncontrolled areas. In rural Africa, however, malaria is not found in small communities, but in a high proportion of the inhabitants of vast territories. There is a large, seldom static, often unco-operative and usually very low density population. The cost of spraying and regular treatment, particularly in using trained reliable staff and finding transport, tends to be high.

With these factors in mind an experiment was carried out to ascertain the reduction of parasite. rate which could be achieved under field conditions with a minimum number of treatments in a high proportion of a reasonably large population as opposed to regular treatment of a small community. The study was undertaken by Dr. E. T. Reid of the Research Laboratory, Salisbury (Central African Journal of Medicine, 8, No. 5; May 1962).

Two similar areas, Fungwe and Chimanda in Southern Rhodesia, were each sprayed with BHC (benzene hexachloride) annually for seven years. After five years parasite-rates remained in the region of 20 per cent and mass chemotherapy was undertaken in one of the areas.

As many people as possible were treated on each of three occasions in the Fungwe area, using a dose of $600 \mathrm{mg}$ chloroquin base and $50 \mathrm{mg}$ pyrimethamine. Treatment was at the beginning of the transmission season in 1959, in the middle of the next non-transmission season and at the end of the second transmission season. Parasite-rates in the area fell rapidly after these experimental treatments from 23.5 per cent to 2.58 per cent during the period of the experiment (18 months). In the control area the parasitelevel remained at approximately 20 per cent. It is considered that malaria control projects in rural Africa do not sufficiently take into account people who, for one reason or another, avoid treatment or having slides taken, and who form foci of infection of unknown importance.

\section{PALAEOLATITUDE OF EVAPORITE DEPOSITS}

\author{
By E. IRVING and J. C. BRIDEN \\ Department of Geophysics, Institute of Advanced Studies, Australian National University, Canberra
}

$I^{\mathrm{N}}$ I many problems connected with Earth science it is useful to make numerical estimates of past latitudes and the directions of crustal features relative to the ancient meridian. Two broad lines of inquiry may be recognized: (1) studies of palæogeography which require estimates of the palæolatitude spectra of (say) a fossil genus or a type of sediment; (2) investigations of structural patterns in the crust relative to the Earth's rotational axis with the view of studying the stress history of the Earth. Palæomagnetic methods afford the means of making these estimates since the measured palæomagnetic inclinations give information on the past latitude, and the declinations information on the azimuth relative to the ancient meridian. As an example of this method results relating to the palæolatitudes of evaporite deposits are discussed in this article.

Evaporite deposits (that is, beds of chlorides and sulphates such as halite, gypsum and anhydrite, etc.) are often taken as indicators of past elimate since they may be supposed to have been laid down in regions of excess evaporation ; for example, their most probable place of occurrence is where temperature is high, at least at some season of the year, and rainfall fairly low. Yet the present geographical distribution of Palæozoic and Mesozoic evaporites ${ }^{1,2}$ is asymmetrical about the Earth's equator (Fig. 4a), the bulk of them being in the northern hemisphere in intermediate or high latitudes often in regions which nowadays experience both heavy rainfall and low temperatures. This could be due to changes in the climatic zones, or changes in land distribution (in particular changes in latitude of the places where evaporites now occur) or to these factors working together. Some workers have suggested that the distribution can be explained in terms of a steady northward shift of evaporite occurrences going back through geological time. The shift has been estimated previously for northern continents at $0.05^{\circ} / \mathrm{m} . \mathrm{y} .{ }^{1}$, and as $0.07^{\circ} / \mathrm{m}$.y. for America and $0 \cdot 11^{\circ} / \mathrm{m} . \mathrm{y}$. for Europe and Africa ${ }^{3}$.

The first numerical estimates of the palæolatitudes of evaporite deposits from the palæomagnetic data were made for beds of Silurian to Triassic age from the United States; the palæolatitude range was calculated to be $0-30^{\circ}$. Afterwards, maps showing the parallels of palæolatitude for Europe and North America were published ${ }^{5-8}$; these confirm, with added details, the range given here. Blackett ${ }^{3}$ has shown that the rate of northward shift of the evaporite occurrences is similar to, but generally less than, the palæolatitude changes calculated from the palæomagnetic data $\left(0.08^{\circ} / \mathrm{m} . \mathrm{y}\right.$. for the Americas and $0 \cdot 14^{\circ} / \mathrm{m}$.y. for Europe). A further result obtained by Blackett $t^{3}$ is that estimates of 'salt latitude' of reference localities made on the basis of an assumed model of the past position of the ancient evaporite zones (the ancient evaporites are assumed to be centred at a latitude of $30^{\circ}$, as appears to be the case nowadays (ref. 2, Fig. 32), yield changes comparable with, but systematically less than, the changes in palæomagnetic latitude; the 'salt latitudes' for the Mesozoic and Palæozoic are less than the palæomagnetic latitudes by about $10^{\circ}$. 